\section{Evaluation of positive radioopaque radiological findings in patients using complete prosthesis}

\section{Tam protez \\ kullanan hastalarda pozitif radyoopak bulguların incelenmesi}

\author{
Assist. Prof. Dr. Fatih Cabbar \\ Yeditepe University, Faculty of Dentistry, Department of \\ Oral and Maxillofacial Surgery, İstanbul
}

Dt. Nevzat Sezer Işıksaçan

Yeditepe University, Faculty of Dentistry, Department of Oral and Maxillofacial Surgery, İstanbul

\section{Dr. Muammer Cağrı Burdurlu}

Yeditepe University, Faculty of Dentistry, Department of Oral and Maxillofacial Surgery, Istanbul

\section{Assoc. Prof. Dr. Ceyda Özçakır Tomruk}

Yeditepe University, Faculty of Dentistry, Department of Oral and Maxillofacial Surgery, İstanbul

Received: 26 July 2017

Accepted: 10 October 2017

doi: 10.5505/yeditepe.2017. 58066

\section{Corresponding author:}

Assist. Prof. Dr. Fatih Cabbar

Yeditepe University, Faculty of Dentistry

Department of Oral and Maxillofacial Surgery

No:238 Bagdat Street 34728 Goztepe İstanbul

Phone: +902163636044

E-mail:fcabbar@gmail.com

\section{SUMMARY}

Aim: The aim of this study was to determine the frequency and localization of the significant radiopaque radiographic findings of patients who edentulous at least one jaw.

Materials and Methods: Panoramic radiographs between 2007 and 2017 were scanned. The radiographs were examined by four investigators; retained root fragments, impacted teeth and radioopacities associated with localized sclerotic bone formation and their localization. Demographic and systemic conditions were also recorded.

Results: Panoramic radiographs from 1391 patients were included in the survey (605 men, 786 women). Positive radioopaque radiographic findings were faced in 107 patients (43 men (40.18\%), 64 women (59.82\%)). 71 retained root fragment, 30 impacted teeth and 6 radioopacities were founded. There was no significant relation with age and sex ( $p>0.05)$.

Conclusion: Routine panoramic examination of the edentulous jaws is valuable to diagnose impacted teeth, retained roots and radioopacities that may require treatment before planning and construction of complete dentures.

Keywords: Complete dentures, positive radiopaque radiologic findings, radioopacity

\section{ÖZET}

Amaç: Bu çalışmanın amacl, en az bir çenede dişsiz olan hastaların radyoopak radyografik bulgularının sıklığını ve lokalizasyonunu belirlemektir.

Gereç ve Yöntem: Çalışmaya 2007 ile 2017 arasında çekilen panaromik radyografiler dahil edildi. Kalan kök parçaları, gömük dişler ve lokalize sklerotik kemik oluşumuna bağlı radyoopasiteler ve bunların lokalizasyonu gibi panoramik bulgular için radyografiler dört araştırmacı tarafından incelendi. Sonuçlar demografik ve sistemik anamnez verileri ile birlikte değerlendirildi.

Bulgular: Pozitif radyoopak bulgular 107 hastada (43 erkek (40.18\%), 64 kadın (59.82\%)) karşılaşıldı. Bu sonuçlara göre 71 adet diş kökü, 30 gömük diş ve 6 radyopasite gözlenmiştir. Cinsiyet ve Yaş ile anlamlı sonuç bulunmadı ( $p>0.05$ ).

Sonuç: Dişsiz çenelerin rutin olarak panoramik muayenesi, planlama yapılmasından ve protezlerin tamamlanmasından önce tedavi gerektiren gömük dişleri, kalan kökleri ve radyoopasiteleri teşhis etmek için faydalıdır.

Anahtar Kelimeler: Total protez, pozitif radyolojik bulgular, radyoopazite

\section{INTRODUCTION}

Aging is bio-psycho-social process that differs among individuals according to their health status, culture and life style. People experience more changes in their bodies as the approach old age then during other stages of life and they need to develop the ability and flexibility to cope with such changes. The biological changes that involved in ageing such as smooth muscle weakness, skeletal muscle atrophy, osteo- 
porosis and fragility of bones and teeth are age related conditions and as such not considered as illnesses. Nevertheless, changes that occur with ageing do limit performance of the bodies organs and tissue and loss of teeth is an important change. ${ }^{1}$

Not replacing missing teeth with stable dentures prevents adequate food intake, resulting in a lack of proper nutrients and vitamins and leading to weight loss and serious medical conditions such as heart disease and poor cognitive function. Replacing missing teeth has to be done as soon as possible after extraction of the teeth. Otherwise the dental problem might become a systemic condition. To replace missing teeth with dentures, radiologic examination is crucial. Therefore, most of the dental practitioners were using panoramic imaging as routine radiologic examination. ${ }^{2,3}$

Panoramic imaging is a technique for producing a single image of the facial structures that includes both the maxillary and the mandibular dental arches and their supporting structures. Radiographic guidelines developed by the US Food and Drug Administration (FDA) and endorsed by the American Dental Association recommend "a full- mouth intraoral radiographic examination or a panoramic examination for the new edentulous patient. The recommendation of pretreatment radiographic examinations for the initial assessment of these patients differs from the guideline for dentate patients, which recommends an individualized radiographic prescription on the basis of selection criteria derived from the clinical examination. The FDA expert panel justified this exception to the principle of selective radiography on the basis of cited literature reporting that "33-41 percent of edentulous patients exhibited radiographic evidence of pathologic conditions. In contrast to the conventional method of reporting total "positive radioopaque findings," a few authors have included an assessment of the impact on treatment of the findings reported. This approach led these authors to question the benefit of routine pretreatment radiography because most of the findings had no impact on treatment. ${ }^{4}$ This study aims to evaluate their positive radioopaque radiologic findings, such as retained root fragments, impacted teeth and radioopacities according to their location.

\section{MATERIALS AND METHODS}

One thousand three hundred ninety-one panoramic radiographs of totally edentulous patients, at least in one jaw, were respectively examined in this study. 1391 patients were treated in Yeditepe University Faculty of Dentistry from 2007 to 2017 . The panoramic x-ray unit was used for all exposures and the films were developed by automatic processing. The radiographs were examined by three experienced specialists. Three authors (FC,
$\mathrm{MCB}, \mathrm{NSI}$ ) independently judged the $\mathrm{x}$-rays and collected the data before a decision was made and arisen conflicts was resolved by analyses of a fourth reader (ZSD). The inclusion criteria were; being edentulous at least one jaw, archived patient's panoramic $x$-ray, being older then 18 years-old. The exclusion criteria was poor panoramic x-ray quality. The following were considered clinically significant positive radioopaque radiographic findings: (1) retained root fragments, (2) impacted teeth, (3) radiopacities associated with localized sclerotic bone formation. Positive radioopaque radiographic findings were also evaluated according to their location in both jaws and with demographic data, smoking, diabetes and sinusitis. In addition, according to the demographic data, age groups divided into 6 categories which are $<40,41$ $50,51-60,61-70$ and $\geq 71$.

In this study data analysis was made by NCSS (Number Cruncher Statistical System) 2007 Statistical Software (Utah, USA).Descriptive statistical methods used for (Standard deviation, cross-section, percentage distribution) data evaluation, in addition comparison between groups are made with the one way analysis of variance, sub-group comparison made with Tukey multiple comparison test, binary groups comparison made with independent $t$ test, qualitative data comparison made with the k-square and fisher reality test. The results are evaluated $p<0.05$ significance level and under $95 \%$ confidence bounds.

\section{RESULTS}

Of the 1391 patients bring in to the examination (Table 1), 605 (43.14\%) were men (Mean: 61.12 -11.65 with the minimum 21, maximum 93), 786 (56.86\%) were women (Mean: 64.38 - 11.68 with the minimum 30, maximum 94).

Table 1. Demographic data of the patients.

\begin{tabular}{|l|l|c|c|}
\hline \multicolumn{2}{|l}{} & n & \% \\
\hline \multirow{5}{*}{ Age Group } & <40 Age & 29 & 2.08 \\
\cline { 2 - 4 } & 41-50 Age & 180 & 12.94 \\
\cline { 2 - 4 } & 51-60 Age & 404 & 29.04 \\
\cline { 2 - 4 } G1-70 Age & 395 & 28.40 \\
\cline { 2 - 4 } Gender & >70 Age & 383 & 27.53 \\
\hline \multirow{4}{*}{ Diabetes } & Male & 605 & 43.49 \\
\hline \multirow{4}{*}{ Hepatitis } & Female & 786 & 56.51 \\
\hline Diagnosed Malignant & No & 1.112 & 79.94 \\
\hline \multirow{3}{*}{ Sumor or Cancer } & Yes & 279 & 20.06 \\
\cline { 2 - 4 } & Yes & 1.311 & 94.25 \\
\hline \multirow{4}{*}{ Sinusitis } & Yo & 80 & 5.75 \\
\cline { 2 - 4 } & No & 1.304 & 93.75 \\
\cline { 2 - 4 } & Yes & 48 & 6.25 \\
\hline & No & 993 & 71.39 \\
\cline { 2 - 4 } & Yes & 398 & 28.61 \\
\hline
\end{tabular}

Positive radioopaque radiographic findings were found in 107 patients $(7.69 \%)$, which $43(40.18 \%)$ were men 
and $64(59.82 \%)$ were women with at least one edentulous jaw. The most common pathology was retained root fragments, moreover radioopacities were seen in low frequency (Table 2).

Table 2. The distribution of radiopacities.

\begin{tabular}{|l|c|c|}
\hline & $\mathbf{n}$ & $\mathbf{\%}$ \\
\hline Retained Root & 71 & 5.10 \\
\hline Impacted Tooth & 30 & 2.16 \\
\hline Radioopacities & 6 & 0.43 \\
\hline
\end{tabular}

Seventy-six root fragments were detected in 71 patients (5.1\%) of 1391 . Out of seventy-six root fragments, thirty-six root fragments $(47.36 \%)$ were observed in upper molar area, and the rarest were seen in upper and lower incisor area. Out of 71 patients who had root fragments, nine patients $(12.67 \%)$ had two, and only one patient $(1.4 \%)$ had three root fragments. Thirty impacted teeth were observed in 30 patients $(2.16 \%)$. Most of them were wisdom teeth and canines were come after the wisdom teeth. Six radioopacities $(0.43 \%)$ were divided equally to three area; lower molar and premolar area and upper molar area. Regarding the retained root fragments, impacted teeth, radioopacities associated with sclerotic bone formation according to sex, 43 pathologies were seen in men and 64 pathologies were seen in women in this study. There was no statistically significant difference between sex groups according to pathology frequency. The patients with pathologies were also divided according to their systemic conditions in their routine anamnesis. The pathologies did not change according to the patient diabetes mellitus condition in this study $(p>0.05)$. Patients with the sinusitis in their systemic anamnesis came up with no statistically significant difference in all groups except radioopacity $(p<0.05)$. Consideration of smoker patients have less pathologies then non-smokers. There was no systematically increase or decrease of the number of pathologies by age $(p>0.05)$.

Table 3. The distribution of radiopacities according to sex.

\begin{tabular}{|l|c|c|c|c|c|}
\hline & \multicolumn{2}{|c|}{ Male } & \multicolumn{2}{c|}{ Female } & p \\
\hline Retained Root & 27 & $4.46 \%$ & 44 & $5.60 \%$ & 0.340 \\
\hline Impacted Tooth & 15 & $2.48 \%$ & 15 & $1.91 \%$ & 0.467 \\
\hline Radioopacities & 1 & $0.17 \%$ & 5 & $0.64 \%$ & 0.184 \\
\hline
\end{tabular}

\section{DISCUSSION}

Many reports have concluded that radiographic screening of all edentulous patients is indicated because of the percentage of positive radiographic findings. In the present study panoramic radiographic examination of 1391 patients revealed that $7.69 \%$ (107 patients) showed 1 or more positive radioopaque radiographic findings.

The most common being retained root fragments which were found in $5.1 \%$ of the patients. According to Sumer., retained roots were the most common finding and followed by impacted teeth and radiolucencies. ${ }^{5}$ Furthermore, previous studies have shown that the most common findings were root fragments. ${ }^{6-8}$ These conclusions were similar like our results. In our study, molar region was the most common area that the most of the root fragments observed. Morphology of the teeth, number and formation of the roots might the major cause of this occasion. Furthermore, posterior parts of the jaws are difficult to perform extraction. Extraction of these roots might result some complications such as, nerve injuries, displacement of these roots to the maxillary sinus. ${ }^{9}$

When we consider the impacted teeth frequency, in our study, $30(2.16 \%)$ impacted teeth were detected. Sumer stated that $3.1 \%$ teeth impaction out of 676 edentulous patients. ${ }^{5}$ Kose reported ${ }^{10}$ (4.8\%) impacted teeth in 743 edentulous patients. ${ }^{10}$ Stathopoulos retrospectively examined 7782 impacted third molars in 6182 patients and stated that pathologic outcomes from the impacted teeth were $2.77 \% .{ }^{11}$ According to Vigneswaran, they examined 2778 patients with impacted third molar, 43 (1.79\%) cases were reported incidence of cyst and tumor. ${ }^{12}$ In our study, we did not detect any pathologic conditions.

Awadreported $^{13}$ (4.8\%) radioopacities in 271 patients. $^{13}$ Sumer stated 41 (12.1\%) localized opacities in 338 patients and this result was slightly more common then the literature. ${ }^{5}$ In our study it was observed $6(0.43 \%)$ localized opacities in 1391 patients. Our finding was parallel with the previous studies.

Positive radioopaque radiographic findings according to the gender, 43 pathologies were seen in men and 64 pathologies were seen in women. Men's 43 pathologies include; 27 root fragments, 15 impacted teeth and 1 radioopacities. Women's 64 pathologies include; 44 root fragments, 15 impacted teeth and 5 radioopacities. Sumer reported men's findings; 23 root fragments, 10 impacted teeth, 17 radioopacities and women's; 29 retained roots, 11 impacted teeth, 24 radioopacities. ${ }^{5}$ Although there was not only statistically significant difference between gender, women's retained root frequency was greater than the men in this study. This might be result of the anxiety that females are more anxious then the males according to Yusa. ${ }^{14}$ Patients with the retained root fragments might have had a bad extraction experience and they might have had increased anxiety after that fail extraction process. This might affect the difference in retained roots between gender. But it is not possible to draw a conclusion for this subject with the present study design.

We found out edentolous patients may have patholog ic conditions which originated from odontogenic structures. At least one panoramic image would give adequate information about the bony structures of upper and lower 
jaw including TMJ. When a practitioner encounter a positive radioopaque findings such as retained root, impacted teeth, radiopacities, practitioner should inform patient about the condition and treatment requirements. The condition that seen in the panoramic x-ray may or may not require treatment, however positive radioopaque findings have to follow-up periodically. This study concludes that panoramic radiographic examination is important in patient examination, even if they are edentulous. However, further studies are necessary for defining the efficacy of panoramic radiographs.

\section{REFERENCES}

1. Hepple RT. Mitochondrial involvement and impact in aging skeletal muscle. Front Aging Neurosci 2014; 6: 211. 2. Adell R, Lekholm U, Rockler B, Branemark PI. A 15-year study of osseointegrated implants in the treatment of the edentulous jaw. Int J Oral Surg 1981; 10: 387-416.

3. Liljestrand JM, Havulinna AS, Paju S, Mannisto S, Salomaa V, Pussinen PJ. Missing Teeth Predict Incident Cardiovascular Events, Diabetes, and Death. J Dent Res 2015; 94: 1055-1062.

4. White SC, Pharoah MJ. Oral Radiology-E-Book: Principles and Interpretation: Elsevier Health Sciences; 2014.

5. Sumer AP, Sumer M, Guler AU, Bicer I. Panoramic radiographic examination of edentulous mouths. Quintessence Int 2007; 38: e399-403.

6. Masood F, Robinson W, Beavers KS, Haney KL. Findings from panoramic radiographs of the edentulous population and review of the literature. Quintessence Int 2007; 38: e298-305.

7. Jindal SK, Sheikh S, Kulkarni S, Singla A. Significance of pre-treatment panoramic radiographic assessment of edentulous patients-a survey. Med Oral Patol Oral Cir Bucal 2011; 16: e600-606.

8. Ansari $\mathrm{IH}$. Panoramic radiographic examination of edentulous jaws. Quintessence Int 1997; 28: 23-26.

9. Arrigoni J, Lambrecht JT. [Complications during and after third molar extraction]. Schweiz Monatsschr Zahnmed 2004; 114: 1271-1286.

10. Kose TE, Demirtas N, Cakir Karabas H, Ozcan I. Evaluation of dental panoramic radiographic findings in edentulous jaws: A retrospective study of 743 patients "Radiographic features in edentulous jaws". J Adv Prosthodont 2015; 7: 380-385.

11. Stathopoulos $P$, Mezitis $M$, Kappatos $C$, Titsinides $S$, Stylogianni E. Cysts and tumors associated with impacted third molars: is prophylactic removal justified? J Oral Maxillofac Surg 2011; 69: 405-408.

12. Vigneswaran AT, Shilpa $S$. The incidence of cysts and tumors associated with impacted third molars. J Pharm Bioallied Sci 2015; 7: S251-254.

13. Awad EA, Al-Dharrab A. Panoramic radiographic examination: a survey of 271 edentulous patients. Int $\mathrm{J}$ Prosthodont 2011; 24: 55-57.

14. Yusa $H$, Onizawa $K$, Hori $M$, . Anxiety measurements in university students undergoing third molar extraction. Oral Surg Oral Med Oral Pathol Oral Radiol Endod 2004; 98: 23-27. 